\title{
THE CONTRIBUTION OF THE ORGANIZATION FOR SECURITY CO-OPERATION IN EUROPE (OSCE) IN THE PROCESSES OF REFORMING AND STRENGTHENING DEMOCRATIC INSTITUTIONS IN THE REPUBLIC OF UZBEKISTAN
}

\author{
Ildar Rafaelivich Azizov, \\ Senior Scientist-researcher of \\ Tashkent State Pedagogical University named after Nizami, \\ Uzbekistan \\ ildar8707@gmail.com
}

http://dx.doi.org/10.26739/2573-5616-2018-3-1-1

\begin{abstract}
The article explores the mechanisms of interaction and cooperation of the Republic of Uzbekistan with the OSCE in the matter of reforming and enhancing the potential of democratic institutions. Issues of cooperation with the NCHR, the Authorized Person of the Oliy Majlis of the Republic of Uzbekistan for Human Rights, supporting the activities of NGOs and other civil society institutions are being considered.

Key words: democracy, Ombudsman, human rights, Oliy Majlis, cooperation, judicial and legal reforms, legislation.

Tzbekistan, having chosen the path of building a democratic state and forming a civil society, relies on the experience gained in developed foreign states. In the practical implementation of the tasks outlined, the OSCE gives much assistance.

The OSCE was created as a "security organization". However, it does not only deal with issues of military security, disarmament or borders. Based on a broad concept of security, the organization also deals with human rights. The OSCE believes that security is more than just the absence of war.[1] In fact, the OSCE participating States, including Uzbekistan, are striving to create a comprehensive framework for peace and stability, both in Europe and abroad. In the Helsinki Final Act, one of the ten guiding principles recognizes "respect for human rights and fundamental freedoms, including freedom of thought, conscience, religion and belief" [2]. This became a cornerstone in the history of human rights protection. For the first time, human rights were included as a clearly formulated
\end{abstract}


constituent element in the framework of regional security on the same basis as military-political and economic issues.

Recent history confirms the validity of the OSCE concept, which states that afree society that allows everyone to take full participation in public life is a guarantee against conflicts and instability. [1] So one example is the fact that exclusion from society of individuals or certain groups, sometimes for ethnic reasons, led to tension, and even armed conflict. Such crises cause the emergence of refugees, most often because of massive violations of human rights. A vivid illustration of this can be the events in neighboring Kyrgyzstan in the summer of 2010.

Many issues related to the establishment of democratic values in the Western world are viewed from the perspective of human interests. In addition, it is quite natural that under the term "human dimension" the OSCE understands a set of norms and activities related to human rights and democracy. Meanwhile, the concept of the "human dimension" is something much larger and more extensive than the problem of human rights. In addition to this, issues of social dimension, culturology, and the humanitarian sphere as a whole should be included in this issue.

Responsibility for the fulfillment of commitments in the field of the human dimension of the OSCE rests with the member countries of the organization. However, in the structure of the organization there are institutions whose activities are related to the human dimension. Namely:

- The Office for Democratic Institutions and Human Rights (ODIHR). The ODIHR, located in Warsaw, is the main OSCE institution responsible for human dimension issues [3].

- OSCE High Commissioner on National Minorities. It was established in The Hague in 1992. The task of this institution is to identify and quickly resolve the situation related to ethnic tension, which could pose a threat to peace, stability and friendly relations between the states participating in the OSCE [3].

- Representative on Freedom of the Media [3].

Strengthening civil society in transitional states, such as Uzbekistan, is the main goal of the ODIHR in the field of democratization, through a number of projects; it strives to establish a constructive dialogue between non-governmental non-profit organizations (NGOs) and representatives of the government or the state on matters affecting civil society and respect for human rights.

In this regard, the First President of the Republic of Uzbekistan, I.A. Karimov, high-ranking at the OSCE Budapest seminar, stressed that "... a difficult but dynamic process of reforming society, becoming political and national self-consciousness of people, spiritual revival and establishment of new democratic values"[4]. 
The construction of a democratic rule-of-law state in Uzbekistan is carried out in order to realize the fundamental principle - "the person is the main value", and not the people should serve state bodies, and state bodies - the people. Now, on the initiative of Sh. M. Mirziyoyev, work has been intensified in this area on perfecting the legislative base, bringing it in line with generally accepted norms and standards in the field of human rights in the world.

In order to create an effective mechanism for protecting human rights and freedoms, expanding cooperation with international and human rights organizations, in October 1996, the National Center for Human Rights was established in Uzbekistan [5], which became a state analytical, advisory, interagency, coordinating body. One of the main tasks of the center is to develop cooperation of the Republic of Uzbekistan with international and national organizations in the field of human rights.

In close cooperation with the OSCE, seminars are regularly held in Tashkent on issues of personal priority. The OSCE Office for Democratic Institutions and Human Rights (ODIHR) plays an important role in organizing these events [6]. For example, a seminar on "National Institutions for Human Rights" held in September 1996 in Tashkent was attended by representatives of OSCE member countries, international, non-governmental and public organizations, mass media. A lively discussion ensued on the development of the activities of the Ombudsman Institute in the countries of Central and Eastern Europe, the improvement of national legislative systems, as well as the role of public education and the media in the field of human rights. Representatives of Denmark, Poland, the United States, Sweden, the Netherlands and other countries shared the results of the activities of national human rights institutions.

The ODIHR, together with the OSCE Office, successfully completed the implementation in 2000 of a program to train monitoring and reporting, as well as strengthen contacts between local activists. Two trainers from the Polish Helsinki Foundation and one of the International League for Human Rights conducted training, which consisted of three sessions. 25 people - representatives of NGOs of Uzbekistan and governmental organizations took part in the program. Based on the success of this program, financed by Germany, the ODIHR conducted similar seminars in other countries of Central Asia [8]. In the same year, representatives of NGOs and the government met in Samarkand. The main goal was to establish a local regional NGO network [8].

In addition, often the Republic of Uzbekistan is visited by representatives of the OSCE legislative bodies, in order to study the state of democratic rights in the country. For example, in November 2005, a delegation headed 
by the Chairman of the Parliamentary Assembly of the Organization for Security and Cooperation in Europe, Els Halstings, visited Uzbekistan. Her meeting with the Speaker of the Legislative Chamber of the Oliy Majlis of the Republic of Uzbekistan took place, during which an exchange of views took place on the issues of bilateral relations between the Parliament of Uzbekistan and the OSCE Parliamentary Assembly [9]. The same meeting was held in April 2007 with the OSCE Chairman-in-Office, Minister of Foreign Affairs and Cooperation of the Kingdom of Spain Miguel Angel Moratinos, who arrived in our republic. Because of the meetings and negotiations, he highly assessed the ongoing changes in the field of democratization of society. In particular, he noted that

"... There are strong democratic institutions in Uzbekistan. We see that a lot of practical work is being done to democratize society, to strengthen security and stability. Uzbekistan makes a worthy contribution to the multifaceted fruitful activity of the OSCE. We highly appreciate constructive cooperation with your country "[9].

The issues related to the formation of the Ombudsman Institute in our country were examined at the February 1997 Scientific and Practical Conference of the Oliy Majlis of the Republic of Uzbekistan "Legislative Basis for the Implementation of Human Rights". The chairpersons of the Oliy Majlis committees, deputies, representatives of the Constitutional and Supreme Courts took part in its work [10].

The status of the Ombudsman in Uzbekistan is enshrined in the relevant law of the Republic of Uzbekistan. Our republic was the first among the CIS countries to have the Institute of the Ombudsman (in this case - Oliy Majlis) for human rights. This became possible due to the achievement in Uzbekistan of political and social stability, the establishment of democratic norms and principles.

With the establishment of the Institute of the Authorized Person for Human Rights of the Oliy Majlis, the tasks of this direction of state activity were determined. In particular, they consist of exercising supervisory functions over the activities of individuals, management bodies through examination and verification of complaints received from citizens. This method is connected with the direct access of the population to the Commissioner for Human Rights and is backed by the principle of free record keeping for all appeals.

Since the establishment of the institution of the Ombudsman of the Oliy Majlis of the Republic of Uzbekistan for Human Rights (Ombudsman), the OSCE actively supports its activities. This support is not only to promote human rights education, but also to organize trainings on effective office work and management. In addition, the improvement of the relevant legislation. 
On the way to improving this institute, conferences and seminars with the participation of OSCE representatives and experts from leading countries of the world were held repeatedly in the republic. For example, on 1-4 May 2000, the ODIHR, in conjunction with the OSCE Liaison Office in Central Asia, held a four-day training seminar for the Uzbek Ombudsman's Office. The seminar was devoted to various aspects of the consideration of complaints and the issues of regionalization of the bureau. In addition, an overview of international human rights standards and concepts was presented to participants. A training seminar on the topic of relations with the courts, law enforcement agencies and the prosecutor's office was held in December 2000. The project was funded by a voluntary contribution from Denmark [11].

In July 2007 in Tashkent hosted a "round table" on the theme: "Actual problems of bringing national legislation into conformity with the Law" On the Authorized Person of Oliy Majlis for Human Rights (Ombudsman) ". In the "round table", except for deputies of the Legislative Chamber and members of the Senate of Oliy Majlis, representatives of OSCE, the diplomatic corps, accredited in Uzbekistan, as well as the institutions of the Ombudsman Russia, Azerbaijan, Spain, prominent legal scholars, experts and specialists. During the discussion it was noted that the Ombudsman, with the support foreign policy Office of the Republic of Uzbekistan and accredited in the country embassies and representations made bilateral and multilateral contacts with ombudsmen many other countries, particularly countries that are members of the OSCE [10].

Thus, the establishment and implementation of broad activities in the Republic of the Institute of the Commissioner for Human Rights of the Oliy Majlis have become a concrete measure to protect the interests of citizens of Uzbekistan.

In the series of events dedicated to socio-political and legal issues occupy a prominent place, and some of the other seminars, conferences, meetings, such as the International Conference "Constitution the Republic of Uzbekistan and human rights", organized by the OSCE Liaison Office in Central Asia, Office of the High Commissioner for Refugees the United Nations with the Constitutional Court of the Republic of Uzbekistan and the University of World Economy and Diplomacy (Tashkent, December 1996) [11]. The head of the OSCE Office addressed the conference for Relations in Central Asia Alois Reznik, as well as well-known social scientists of our country. During the discussion, the Constitution of the Republic of Uzbekistan was highly appreciated, in which the theme of human rights and freedoms holds a special place.

It is important to note the fact that today our country has joined more than 20 international treaties on the protection of human rights. However, at the same time, speaking of international treaties, as well as normative 
documents, it should be emphasized that for all states that have joined international documents, one of the important norms is the obligation to publish and widely disseminate these documents in their country. It is known that the international documents, to which the Republic of Uzbekistan has acceded, are mostly represented in the official languages of the UN, either in Russian or in English. Today's practice shows that in order for these materials to be available to a wide range of readers of our country, it is necessary to organize their publication in the state language.

A certain work is being done in this direction in Uzbekistan.

In particular, in September 2002 a presentation of the OSCE Human Dimension Document Collection in the Uzbek language was held at the Intercontinental Hotel in Moscow[11].

Moreover, the fact that Uzbekistan became a party to many international treaties certainly creates favorable conditions for the cooperation of the republic with democracies in Europe in the humanitarian and human rights spheres. In particular, in February 1997, in Tashkent, on the initiative of the National Center of the Republic of Uzbekistan for Human Rights and the Tashkent State Institute of Law, a seminar was held on the theme: "Human rights: the experience of France and Uzbekistan". Representatives of the UN missions, OSCE in Uzbekistan, embassies of foreign countries in our country, heads of centers and institutions dealing with the study of human rights problems, scientists and specialists attended the event [11].

In May 1997, the ODIHR conducted the first course of the human rights education program in Uzbekistan. This course was attended by about 30 participants, including local level leaders, university lecturers and representatives of NGOs. In February and March 1998, the ODIHR conducted an assessment of the region's needs in order to continue this program in four other Central Asian countries: Kazakhstan, Kyrgyzstan, Tajikistan and Turkmenistan.

The second course of the human rights education program was held in May 1998 in Tashkent by the professor of Birmingham University, Mr. Mack Bryde and Ms Christina Miskowiak, representative of the Danish Center for Human Rights. The second course was attended by 26 participants, who were represented by various governmental structures, NGOs, research institutes and universities of five Central Asian states. The main topics of discussion were:

1. Philosophical substantiation of human rights

2. Human rights and international order

3. Human rights, democracy and the rule of law

4. International obligations and actions on the ground

5. International law enforcement mechanisms

6. The OSCE Human Dimension Concept 
The Tashkent course was completed by conducting an assessment of the level of understanding and mastering by the partici pants of the seminar of the topics discussed.Based on the results of this assessment, 15 participants were selected to attend an advanced course in Denmark in October 1998 with the assistance of Professor McBride [8].

Thus, close contacts have been established between the Republic of Uzbekistan and the OSCE on the issues of reforming and strengthening democratic institutions.

Uzbekistan's interaction with such authoritative international organizations substantially increases the potential of reforms in the country, as well as the implementation of new forms and methods of protecting legitimate human rights and interests, improving the mechanism of legal services, etc.

\section{References}

1. OSCE commitments in the field of the human dimension. Reference manual. Vein. 1996, p. 14;

2. Helsinki Final Act. 1975 with 2;

3. OSCE Human Dimension Implementation Meeting. Warsaw. 2009 c. 6-7;

4. Decree of the President of the Republic of Uzbekistan on the creation of the National Center for Human Rights of the Republic of Uzbekistan // Vedomosti of the OliyMajlis of the Republic of Uzbekistan. 1996. № 10. p. 45-46;

5. Karimov Islam. Our goal: a free and prosperous homeland. from. 328;

6. OSCE / ODIHR Report 1996, from 29-61;

7.Diplomatic panorama...1997.- №7.C.51-55;

8. ODIHR mid-year report Spring 1998 Warsaw. P.33-37;

9. The people's word. from 4 March 1997, 13 July 2007, 26 September 2002.

10. Annual report of the year 2000. Office for Democratic Institutions and Human Rights. Warsaw, 2000. P.18;

11. A. Saidov National Center of the Republic of Uzbekistan for Human Rights. 19961998. T.: 1998. P.40 